\title{
Does advance contact with research participants increase response to questionnaires: A Systematic Review and meta-Analysis
}

\author{
Benjamin Woolf ${ }^{1,2,3}$, Phil Edwards ${ }^{3}$ \\ ${ }^{1}$ Department of Psychological Science, University of Bristol, Bristol, UK \\ ${ }^{2}$ Medical Research Council Integrative Epidemiology Unit, University of Bristol, Bristol, UK \\ ${ }^{3}$ Faculty of Epidemiology and Population Health, London School of Hygiene and Tropical Medicine, \\ London, UK
}

Corresponding Author:

Benjamin Woolf

Department of Psychological Science,

5 Priory Road,

Bristol,

BS8 1TU

Email address: Benjamin.woolf@bristol.ac.uk

\section{Abstract}

Background: Questionnaires remain one of the most common forms of data collection in epidemiology, psychology and other human-sciences. However, results can be badly affected by non-response. One way to potentially reduce non-response is by sending potential study participants advance communication. The last systematic review to examine the effect of questionnaire pre-notification on response is ten years old, and lacked a risk of bias assessment.

Objectives: Update Edwards et al. (2009) to include 1) recently published studies, 2) an assessment of risk of bias.

Methods: Data sources: Edwards et al. (2009); 13 data-bases; the references in, and citations of included studies. Eligibility criteria: Randomised control trials examining the impact of pre-notification on response. Data extraction: data extraction was done twice by a single unblinded reviewer. Risk of bias was assessed using the Cochrane Risk of Bias tool and funnel plots.

Results: 103 trials were included. Over-all pre-notification increased response, $\mathrm{OR}=1.38$ $(95 \% \mathrm{Cl}: 1.25-1.53)$. However, when studies at high or unclear risk of bias were excluded the effect was greatly reduced (OR $=1.11,95 \% \mathrm{Cl}: 1.01-1.21$ ). 
medRxiv preprint doi: https://doi.org/10.1101/2021.02.19.21252094; this version posted February 23, 2021. The copyright holder for this preprint (which was not certified by peer review) is the author/funder, who has granted medRxiv a license to display the preprint in perpetuity. It is made available under a CC-BY-NC-ND 4.0 International license.

2

Conclusions: The evidence implies that while pre-notification does increase response rates, this may not be of clinical utility. 


\section{Background}

\section{Introduction}

Questionnaires have been one of the most common methods of data collection across the social and medical sciences. For example, in epidemiology pen and paper questionnaires alone were used in $29.2 \%$ of over 2,000 analytic epidemiological studies included in a review of articles published in high-impact medical journals between 2008 and 2009. ${ }^{1}$ Likewise, about a third of empirical research published in management and accounting journals use questionnaires, and a review of a top social psychology journal found that over $91 \%$ of empirical studies published in the second half of 2017 used some form of questionnaire. ${ }^{23}$

Inherent in using questionnaires is a risk of non-response. Potential participants, for example, might forget to complete questionnaires, and research ethics requires a right to refuse participation. Non-response can negatively impact on studies in three major ways: Firstly, non-response can introduce selection bias. ${ }^{4}$ Secondly, even in the absence of selection bias, because non-response reduces the number of participants recruited into a study, non-response increases risk of random error (i.e. reduces statistical power and precision). Finally, non-response increases study costs. ${ }^{5}$

It is therefore important to minimise non-response. One potential method is for the study team to contact potential participants in advance of them receiving the questionnaire (questionnaire pre-notification). In 2009, Edwards et al. published a systematic review of randomised control trials evaluating methods of reducing non-response in both postal and electronic questionnaires. ${ }^{6}$ They found that pre-contact increased response when compared to no pre-contact $(\mathrm{OR}=1.5,95 \% \mathrm{Cl} 1.26-1.78$, for response after first questionnaire administration, and $\mathrm{OR}=1.45,95 \% \mathrm{Cl} 1.29-1.63$ for response after final questionnaire administration). However, Edwards et al. (2009) did not assess the risk of bias in or across the included studies, and is now 10 years old, so therefore does not include research published in the last decade.

There is therefore a need for an updated review which includes recently published studies, an assessment of bias risk in and across included studies. This review will:

1. Update Edwards et al. (2009)'s systematic review and meta-analysis of randomised control trials examining the effect on non-response of pre-notification relative to no pre-notification (in any population) so that it includes papers published in the last decade.

2. To carry out an assessment of the risk of bias (i) in and (ii) across included studies.

\section{Protocol and registration}

\section{Methods}

The methodology of the review and analysis was approved in advance by the LSHTM epidemiology MSc course directors. A copy of this form, approved on 21/03/2018, can be found in Supplementary Table 1.

This study received ethics approval from the London School of Hygiene and Tropical Medicine MSc Research Ethics Committee on 26/03/2018.

\section{Eligibility criteria}

Inclusion criteria

Types of population: This study followed Edwards et al. (2009) in using data from "[a]ny population (e.g. patients or healthcare providers and including any participants of non-health studies)." This should maximise generalisability over different contexts. 
medRxiv preprint doi: https://doi.org/10.1101/2021.02.19.21252094; this version posted February 23, 2021. The copyright holder for this preprint (which was not certified by peer review) is the author/funder, who has granted medRxiv a license to display the preprint in perpetuity. It is made available under a CC-BY-NC-ND 4.0 International license.

Types of interventions: interventions must include some type of questionnaire precontact (pre-notification, advance letter/email/text/phone call or other co-referring term). No restriction is placed on the type of questionnaire pre-notification.

Comparison group: Included studies need to be able to make a direct comparison of the effect of questionnaire pre-notification vs no pre-notification (i.e. include at least one arm which received identical treatment to the pre-notification arm other than not receiving the pre-notification).

Types of outcome measures: The proportion or number of completed, or partially completed questionnaires returned after all follow-up contacts were complete.

Types of study design: Any randomised control trial evaluating a method of advanced contact to increase response to questionnaires. The inclusion of only randomised control trials should on average eliminate risk of confounding biasing estimates within studies.

Exclusion criteria

There are no exclusion criteria.

\section{Information sources}

1. Relevant studies identified by Edwards et al. (2009). A detailed description of the information sources, e.g. databases with dates of coverage, used in this study are in its methods section and Supplementary Tables, which can be freely accessed in the Cochrane Library (https://www.cochranelibrary.com/cdsr/doi/10.1002/14651858.MR000008.pub4/full).

2. A search in the same data-bases used in Edwards et al. (2009) from the date they were last searched till the present day. Specifically, the following databases were searched (with date restrictions in brackets): CINAHL (2007.12-2018.6); Dissertation \& Thesis, Social Science Citation Index, Science Citation Index, and Index to Scientific \& Technical Proceedings in Web of Science (2008.1-2018.6); Psyclnfo (2008.1-2018.6); MEDLINE (2007.1-2018.6); EconLit (2008.1-2018.6); EMBASE (2008.1-2018.6); Cochrane Central (2008.1-2018.6); Cochrane CMR (2008.1-2018.6); ERIC (2008.1-2018.6); and Sociological Abstracts (2007.1-2018.6). After consultation with the LSHTM library, two databases searched by Edwards et al. (2009) (National Research Register and Social Psychological Educational Criminological Trials Register) were not searched because they were both deemed inaccessible and no longer operational. Any relevant reviews found in the literature search were examined for relevant studies

3. The references of all included studies, and any citation they, or Edwards et al. (2009), had received by the $28 / 6 / 2018$ were checked for meeting the eligibility criteria.

Non-English papers were translated using Google Translate.

\section{Search strategy}

The search strategy was developed by modifying the strategy used by Edwards et al. (2009), to make it more sensitive and specific to detecting studies examining questionnaire prenotification, by adding terms denoting types of pre-notification, and removing terms relating to other methods. The strategy was validated by inputting the new terms into Google Scholar, and checking that it detected all relevant studies included in Edwards et al. (2009). The specific search terms are presenting in Supplementary Table 7.

\section{Study selection}

The eligibility assessment was conducted by one reviewer following a standardised procedure. This process was repeated on a random $10 \%$ by a second reviewer with $99.7 \%$ 
medRxiv preprint doi: https://doi.org/10.1101/2021.02.19.21252094; this version posted February 23, 2021. The copyright holder for this preprint

(which was not certified by peer review) is the author/funder, who has granted medRxiv a license to display the preprint in perpetuity.

It is made available under a CC-BY-NC-ND 4.0 International license .

agreement. Citations were uploaded onto Covidence (http://www.covidence.org/), a website specially designed for paper screening by the Cochrane Collaboration. Covidence automatically identified duplicates of citation/abstracts, which were then manually checked for errors.

Studies were first screened based on abstracts and titles, then full text. This process was repeated for any study which was referenced by or itself cited by an included study, and on the content of any potentially relevant review identified in the search.

\section{Data collection process}

A standardised data extraction sheet (Supplementary Table 2) was developed. The sheet was pilot tested on 10 randomly chosen studies from Edwards et al. (2009). One reviewer extracted data from included studies. To minimise transcription errors, this process was later duplicated. Authors were contacted for extra information about study bias risk, and still existent copies of communication from Edwards et al. (2009) were examined.

To check for duplication studies which shared at least one author were compared based on similarity of study population, date, and methodology. Duplicate trials were treated as a single study in the meta-analysis.

\section{Data items}

Information extracted for each included trial comprised 5 domains:

1) Information on the inclusion criteria: The study design, nature of the control arm, information on the intervention arm(s), information about the outcome measurement (the number of responses, and/or the response rate, in each arm).

2) Information on risk of bias: how the allocation sequence was generated, information of allocation concealment, blinding of participants and personnel, blinding of outcome assessors, any incomplete outcome data, information on other possible sources of bias (e.g. source of funding).

3) Information on the participants: the total number of participants, numbers in each arm, setting, country.

4) Information on the outcome: number of items returned, or response rate, in each arm.

5) Other information: the time from the sending of pre-notification to questionnaire, if it includes a foot-in-the-door manipulation, the type of questionnaire administration, the type of pre-contact.

\section{Risk of bias in individual studies}

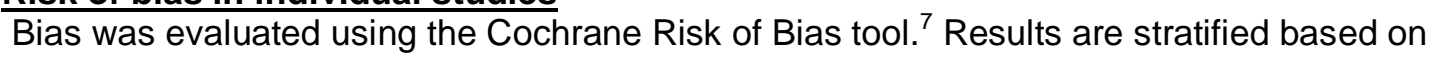
Risk of Bias score.

\section{Summary measures}

The primary summary measure of association estimated was the ratio of the odds (OR) of response in the treatment groups compared with the odds of response in the control group.

In line with Edwards et al. (2009), the meta-analyses were performed by comparing the ORs using a random-effects model. The analysis was performed on an intention-to-treat basis. Outcomes were only included if they occurred within the period of follow up.

\section{Synthesis of results/Planned methods of analysis}

The results were synthesised in a meta-analysis conducted using STATA 15, using the 'metan' command. ${ }^{8}$ To be consistent with Edwards et al. (2009), a random effects metaanalysis was used. Heterogeneity was assessed using the Cochran-Q Chi ${ }^{2}$ statistical test for heterogeneity, and the $\mathrm{I}^{2}$ statistic. $^{9}$

\section{Risk of bias across studies}


medRxiv preprint doi: https://doi.org/10.1101/2021.02.19.21252094; this version posted February 23, 2021. The copyright holder for this preprint

(which was not certified by peer review) is the author/funder, who has granted medRxiv a license to display the preprint in perpetuity.

It is made available under a CC-BY-NC-ND 4.0 International license.

Risk of bias across studies was assessed with funnel plots. Asymmetry was investigated informally, by visually assessing how symmetrical the plots are around the effect estimate, and formally, using Harbord's test. Funnel plots were created using the 'metafunnel' command in STATA. Because ORs are naturally correlated with their standard error, response rates were used instead of ORs. ${ }^{8}$

\section{Study section}

\section{Results}

A total of 99 papers, reporting a total of 103 trials, were identified for inclusion in the review. The search resulted in a total of 26,894 citations, including 11,408 duplications. The reasons for exclusions are stated in Figure 1 and Supplementary Table 4. The numbers identified and excluded at each stage are described Figure 1.

\section{Study characteristics}

The characteristics of the included studies are described in detail in Supplementary Table 5.

\section{Risk of bias within studies}

Judgments formed for each domain of the Cochrane Risk of Bias tool in each study are represented graphically in Figure 2. The supporting evidence can be found in Supplementary Table 6. Overall, 8 studies were at high risk, 8 at low risk and 87 were at unclear risk. The proportions of studies at each level of risk is presented in Figure 3.

\section{Sequence generation}

32 studies described the process used to generate the random sequence, or confirmed the use of randomisation in correspondence. 3 did not use random allocation. 68 studies have an uncertain risk of bias.

Allocation concealment

39 studies described concealment, or confirmed it in communication. 5 confirmed that they had not used allocation concealment in communication. The remaining 69 studies provided insufficient information to reach a judgment, and so are of unclear bias.

\section{Participant and personnel blinding}

Participant and personnel blinding was not reported most trials. However, the design of many trials ensured that a degree of blinding did occur. A common design was to randomise participants to receive or not to receive a pre-notification without prior consent. The prenotification itself would also often not explain that the participant had been allocated to receive it randomly. Thus any effect of treatment could not be due to the effect of knowing that they had been specially selected for an intervention which others had not got. Although the participant still knew they had received the pre-notification, this knowledge is part of the effect of a pre-notification - and therefore does not introduce any risk of material bias.

Similarly, although most did not describe any blinding procedure for personnel, its absence was often unlikely to lead to bias in estimates. In studies using a pre-written pre-contact (e.g. e-mail, letters, SMS) unblinded study personnel do not have the ability to influence the experience or perceptions of potential participants, as their only means of communication with each other is through a pre-written pro-forma message. This, however, is not true for studies which used a telephone pre-notification, in which the personnel and potential participants can have a genuine interaction. No study with telephone pre-notification reported no blinding of personnel. 
Overall 88 studies were regarded as being at low risk of bias, and 15 at unclear risk.

\section{Blinding of outcome assessment}

Outcome assessment blinding was reported in 8 studies. However, the outcome (whether the questionnaire had been returned) is objective, and unlikely to be influenced by whether the outcome assessor knows the group assignment. Because the analyses are a comparison of two proportions, data analysers were unlikely to have enough researcher degrees of freedom for bias to be introduced in the analyses. All studies were therefore judged as being at low risk of bias for this domain.

Incomplete outcome data

98 provided enough information to ascertain the total number of participants randomised in each arm and the total number of questionnaires returned in each arm. However, 4 are at unclear risk because they did not report sufficient detail to estimate per protocol rates, or state if the rates were intention to treat or per protocol, and one study at high risk.

\section{Selective reporting}

There was little evidence of selective reporting. All studies reported information on the relevant outcomes of interest.

Other biases.

3 of the factorial studies had significant interaction effects.

\section{Results of individual studies}

The results from individual studies are presented in a forest plot, Figure 4.

\section{Synthesis of results}

Information on response was available in all trials, thus data from all trials was used. These randomised a total of 338,429 participants, and had 174,323 returned questionnaires. The pooled estimate shows an increase in response for the final follow-up after questionnaire pre-notification (OR $=1.38,95 \% \mathrm{Cl}: 1.25-1.53, \mathrm{p}<0.001)$. There was strong evidence of heterogeneity $\left(I^{2}=96.9 \% ; \operatorname{Tau}^{2}=0.24 ; X^{2}(102, N=103)=3311.86, p<0.001\right)$

\section{Risk of bias across studies}

To explore the possibility of small study bias, funnel plots were created for both outcomes, Figures 5. Visual assessment implies that there is no major asymmetry. However, more studies than expected fell outside the $95 \%$ confidence limits. In addition, a formal assessment of asymmetry, using Harbord's test, did not find evidence to reject the null hypothesis of no asymmetry ( $p=0.577)$.

\section{Risk of Bias Within Studies}

87 studies were at unclear risk, 8 at low risk, and 8 at high. When stratified by risk of bias, there was no longer evidence against the assumption of pooled association across studies which were of low bias $(\mathrm{OR}=1.11,95 \% \mathrm{Cl}$ : $1.01-1.21 \mathrm{p}=0.027)$. There was evidence of an association among studies of uncertain risk $(\mathrm{OR}=1.45,95 \% \mathrm{Cl}: 1.27-1.66, \mathrm{p}<0.001)$ and high risk $(\mathrm{OR}=1.50,95 \% \mathrm{Cl}: 1.20-1.86, \mathrm{p}<0.001)$. Heterogeneity was reduced in in both the low $\left(I^{2}=62.2 \%\right.$; $\left.\operatorname{Tau}^{2}=0.02 ; X^{2}(19)=50.21, p<0.001\right)$ and high $\left(I^{2}=87.1 \% ; \mathrm{Tau}^{2}=\right.$ $\left.0.11 ; X^{2}(10)=77.37, p<0.001\right)$ risk groups, but not the unclear risk group $\left(\mathrm{I}^{2}=97.6 \%\right.$; $\mathrm{Tau}^{2}$ $\left.=0.29 ; X^{2}(71)=2981.94, \mathrm{p}<0.001\right)$. Results displayed in Figure 6 .

\section{Discussion and conclusions}


medRxiv preprint doi: https://doi.org/10.1101/2021.02.19.21252094; this version posted February 23, 2021. The copyright holder for this preprint

(which was not certified by peer review) is the author/funder, who has granted medRxiv a license to display the preprint in perpetuity.

It is made available under a CC-BY-NC-ND 4.0 International license .

\section{Summary and interpretation of evidence}

This meta-analysis and systematic review of randomised control trials examined the effect of pre-notification compared to no pre-notification on questionnaire response rates. Prenotification led to $1.38(95 \% \mathrm{Cl}: 1.25-1.53)$ times greater odds for response. However, this was greatly reduced after restricting to studies of low risk of bias, OR $=1.11(95 \% \mathrm{Cl}: 1.01$ 1.21). This low OR implies that researchers should be cautious when using pre-notification as they may not be cost effective or lead to improvements of clinical relevance.

\section{Limitations}

Outcome level limitations

\section{Risk of Bias:}

Across domains, high risk of bias was uncommon. However, few studies provided sufficient information to be assigned low risk of bias. The age of many studies makes communication difficult, e.g. due to address change.

\section{Imprecision:}

Due to the large number of participants in each arm, even after stratification by bias risk, confidence intervals were relatively narrow.

\section{Indirectness:}

There was generally little indirectness in the review. All studies were randomised control trials examining the effect of pre-notification on questionnaire response, so directly answered the study question. However, it is unclear if the study will generalise to any population. For example, there are no studies from low income countries.

\section{Publication bias:}

Visual inspection of the funnel plots and formal testing with Harbord's test both imply that small study bias was unlikely. As high questionnaire response is important to nonacademics, e.g. polling companies, an unassessed grey literature will probably exist.

\section{Heterogeneity:}

There was substantive heterogeneity within the study. Future studies should consider further explanations.

\section{Review level limitations}

\section{Search strategy}

Cochrane recommends that the literature searching be done by two independent reviewers, while this study only used one..$^{10}$ In addition, the search lacked specificity, and some extra publications might have been found by contacting authors to see if they had published other studies on the question. However, citation searching is not always common in systematic reviews, although it proved an effective way of detecting new studies.

\section{Data extraction}


medRxiv preprint doi: https://doi.org/10.1101/2021.02.19.21252094; this version posted February 23, 2021. The copyright holder for this preprint

(which was not certified by peer review) is the author/funder, who has granted medRxiv a license to display the preprint in perpetuity.

It is made available under a CC-BY-NC-ND 4.0 International license .

Cochrane recommends that data extraction should be done by two independent reviewers, while this study only used one, which should also reduce errors. ${ }^{11}$

\section{Analysis}

\section{Strengths and weaknesses in relation to other studies}

The updated review more than doubled the number of included studies, and four old studies were excluded for poor methodology. The overall results of the two studies are relatively similar, with overlapping confidence intervals overlap the results of the two studies might be consistent. However, restricting to low risk of bias studies implies that this estimate may be due to study bias.

Both studies might be criticised for their choice of outcomes. Response rate does not entail response quality. ${ }^{5}$ For example, a questionnaire might not have been fully completed, or completed inaccurately. In addition, to be a useful intervention for researchers prenotification needs to be cost effective. However, neither of these outcomes are examined in the reviews.

\section{Conclusion}

This systematic review and meta-analyses of randomised control trials examining the effect of pre-notification on questionnaire response found evidence which supports the use of prenotification. However, after excluding studies at high or unclear risk of bias the effect of the intervention was greatly reduced, and is probably no longer of clinical relevance.

\section{References}

1. Gelder V, J MMH, Bretveld RW, Roeleveld N. Web-based Questionnaires: The Future in Epidemiology? Am J Epidemiol. 2010 Dec 1;172(11):1292-8.

2. Doliński D. Is Psychology Still a Science of Behaviour? Social Psychological Bulletin. 2018 May 29;13(2):e25025.

3. Van der Stede WA, Young SM, Chen CX. Assessing the quality of evidence in empirical management accounting research: The case of survey studies. Accounting, Organizations and Society. 2005 Oct 1;30(7):655-84.

4. Scott Patten, SPMF. Epidemiology for Canadian Students: Principles, Methods and Critical Appraisal. 1 edition. Brush Education; 2015. 304

5. Vogl S. Advance Letters in a Telephone Survey on Domestic Violence: Effect on Unit Nonresponse and Reporting. Int J Public Opin Res [Internet]. [cited 2018 Aug 29];

Available from: https://academic.oup.com/ijpor/advancearticle/doi/10.1093/ijpor/edy006/4944573

6. Edwards PJ, Roberts I, Clarke MJ, Diguiseppi C, Wentz R, Kwan I, et al. Methods to increase response to postal and electronic questionnaires. Cochrane Database Syst Rev. 2009 Jul 8;(3):MR000008.

7. Higgins JPT, Altman DG, Sterne JAC (editors). Chapter 8: Assessing risk of bias in included stuides. In: Higgins JPT, Green S (editors), Cochrane Handbook for Systematic Reviews of Interventions. Version 5.2.0 [updated June 2017]. The Cochrane Collaboration, 2017. Available from www.cochrane-handbook.org.

8. Higgins JPT, Deeks JJ (editors). Chapter 16: Speical topics in statistics. In: Higgins JPT, Green S (editors), Cochrane Handbook for Systematic Reviews of 
medRxiv preprint doi: https://doi.org/10.1101/2021.02.19.21252094; this version posted February 23, 2021. The copyright holder for this preprint

(which was not certified by peer review) is the author/funder, who has granted medRxiv a license to display the preprint in perpetuity.

It is made available under a CC-BY-NC-ND 4.0 International license .

Interventions. Version 5.1.0 [updated March 2011]. The Cochrane Collaboration, 2011. Available from www.cochrane-handbook.org.

9. Sterne JAC, Egger M, Moher D, Boutron I (editors). Chapter 10: Addressing reporting biases. In: Higgins JPT, Churchill R, Chandler J, Cumpston MS (editors), Cochrane Handbook for Systematic Reviews of Interventions version 5.2.0 (updated June 2017), Cochrane, 2017. Available from www.training.cochrane.org/handbook.

10. Lefebvre C, Manheimer E, Glanville J. Chapter 6: Searching for studies. In: Higgins JPT, Green S (editors), Cochrane Handbook for Systematic Reviews of Interventions. Version 5.1.0 [updated March 2011]. The Cochrane Collaboration, 2011. Available from www.cochrane-handbook.org.

11. Eldridge S, Campbell M, Campbell M, Dahota A, Giraudeau B, Higgins J, Reeves B, Siegfried N. Revised Cochrane risk of bias tool for randomized trials (RoB 2.0): additional considerations for cluster-randomized trials.

12. Waisanen FB. A note on the response to a mailed questionnaire. Public Opinion Quarterly 1954;18:210-2.

13. Vogl S. Advance Letters in a Telephone Survey on Domestic Violence: Effect on Unit Nonresponse and Reporting. Int J Public Opin Res [Internet]. [cited 2018 Aug 29]; Available from: https://academic.oup.com/ijpor/advancearticle/doi/10.1093/ijpor/edy006/4944573

14. Jobber $D$, Sanderson $S$. The effect of two variables on industrial mail survey returns. Industrial Marketing Management 1985;14:119-21.

15. Heaton $E$. Increasing mail questionnaire returns with a preliminary letter. Journal of Advertising Research 1965;5: 36-9.

16. Taylor S, Lynn P. The effect of a preliminary notification letter on response to a postal survey of young people. The Journal of the Market Research Society 1998;40(2):165-73.

17. Walker BJ, Burdick RK. Advance Correspondence and Error in Mail Surveys. Journal of Marketing Research. 1977;14(3):379-82

18. Hansen RA, Robinson LM. Testing the effectiveness of alternative foot-in-the-door manipulations. Journal of Marketing Research 1980;17:359-64.

19. Atinc M, Yasmin O. Response rate and response error in marketing research ProQuest [Internet]. 2012 [cited 2018 Aug 29]. Available from: https://search.proquest.com/openview/912c161dd4b8a19d6371453f420dd30a/1 ?pqorigsite $=$ gscholar $\& \mathrm{cbl}=18750 \&$ diss $=y$

20. Barra M, Simonsen TB, Dahl FA. Pre-contact by telephone increases response rates to postal questionnaires in a population of stroke patients: an open ended randomized controlled trial. BMC Health Services Research. 2016 Sep 21;16(1):506.

21. Baulne $J$, Courtemanche $R$. Is there really any benefit in sending out introductory letters in Random Digit Dialling (RDD) surveys? - ARCHIVED [Internet]. 2009 [cited 2018 Aug 29]. Available from: https://www150.statcan.gc.ca/n1/pub/11-522x/2008000/article/11001-eng.pdf

22. Bauman A, Phongsavan P, Cowle A, Banks E, Jorm L, Rogers K, et al. Maximising follow-up participation rates in a large scale 45 and Up Study in Australia. Emerg Themes Epidemiol. 2016;13:6.

23. Beebe TJ, Rey E, Ziegenfuss JY, Jenkins S, Lackore K, Talley NJ, et al. Shortening a survey and using alternative forms of prenotification: Impact on response rate and quality. BMC Medical Research Methodology. 2010 Jun 8;10(1):50.

24. Bergsten JW, Weeks MF, Bryan FA. Effects of an Advance Telephone Call in a Personal Interview Survey. The Public Opinion Quarterly. 1984;48(3):650-7.

25. Bhutta MF, Hobson L, Lambie J, Scaman ESH, Burton MJ, Giele H, et al. Alternative Recruitment Strategies Influence Saliva Sample Return Rates in Community-Based Genetic Association Studies. Annals of Human Genetics. 2013 May 1;77(3):244-50.

26. Boser JA. Variations in Mail Survey Procedures: Comparison of Response Rates and Cost [Internet]. 1990 [cited 2018 Aug 29]. Available from:

https://eric.ed.gov/?id=ED319803 
medRxiv preprint doi: https://doi.org/10.1101/2021.02.19.21252094; this version posted February 23, 2021. The copyright holder for this preprint (which was not certified by peer review) is the author/funder, who has granted medRxiv a license to display the preprint in perpetuity. It is made available under a CC-BY-NC-ND 4.0 International license.

27. Boyd A, Tilling K, Cornish R, Davies A, Humphries K, Macleod J. Professionally designed information materials and telephone reminders improved consent response rates: evidence from an RCT nested within a cohort study. J Clin Epidemiol. 2015 Aug;68(8):877-87.

28. Brehm J. Stubbing our toes for a foot in the door? Prior contact, incentives and survey response. Int J Public Opin Res. 1994 Mar 1;6(1):45-63.

29. Brick JM, Collins MA. A Response Rate Experiment for RDD Surveys. In: Proceedings of the American Statistical Association, Survey Research Methods Section. 1997. p. 1052-1057.

30. Camburn D, Inc AA, Lavrakas PJ, Battaglia MP. Using advance respondent letters in random-digit-dialing telephone surveys. In: Proceedings of the American Statistical Association Section on Survey Methods. 1995. p. 96997-4.

31. Chebat J-C, Cohen A. EBSCOhost | 9602160676 | Response speed in mail surveys: Beware of shortcuts. [Internet]. 1993 [cited 2018 Aug 29]. Available from: https://web.b.ebscohost.com/abstract?direct=true \&profile=ehost\&scope=site\&authtyp $\mathrm{e}=$ crawler\&jrnl $=10408460 \& a s a=Y \& A N=9602160676 \& \mathrm{~h}=0 \mathrm{pO}$ - $4 \mathrm{bHcen6Nw9NApZ5Uu}$ SfC\%2bnykPtqMNh2\%2bcmZtexko8G0KnRPsoycj5k9qLEJqkFFZxkAK7od4ajkWT\% $2 \mathrm{bhxvw} \% 3 \mathrm{~d} \% 3 \mathrm{~d} \& \mathrm{crl}=\mathrm{c} \&$ resultNs=AdminWebAuth\&resultLocal=ErrCrINotAuth\&crlhas hurl=login.aspx\%3fdirect\%3dtrue\%26profile\%3dehost\%26scope\%3dsite\%26authtyp e\%3dcrawler\%26jrnl\%3d10408460\%26asa\%3dY\%26AN\%3d9602160676

32. Dillman DA, Gallegos JG, Frey JH. Reducing Refusal Rates for Telephone Interviews. Public Opin Q. 1976 Jan 1;40(1):66-78.

33. Duncan A, Zajac I, Flight I, Stewart BJ, Wilson C, Turnbull D. Comparison of mailed invitation strategies to improve fecal occult blood test participation in men: protocol for a randomized controlled trial. Trials. 2013 Jul 31;14(1):239.

34. Dykema J, Stevenson J, Day B, Sellers SL, Bonham VL. Effects of incentives and prenotification on response rates and costs in a national web survey of physicians. Eval Health Prof. 2011 Dec;34(4):434-47.

35. Dykema J, Stevenson J, Klein L, Kim Y, Day B. Effects of E-Mailed Versus Mailed Invitations and Incentives on Response Rates, Data Quality, and Costs in a Web Survey of University Faculty. Social Science Computer Review. 2013 Jun 1;31(3):359-70.

36. Edelman LS, Yang R, Guymon M, Olson LM. Survey Methods and Response Rates Among Rural Community Dwelling Older Adults. Nursing Research. 2013 Aug;62(4):286.

37. Edwards L, Salisbury C, Horspool K, Foster A, Garner K, Montgomery AA. Increasing follow-up questionnaire response rates in a randomized controlled trial of telehealth for depression: three embedded controlled studies. Trials. 2016 Feb 24;17(1):107.

38. Edwards P, Roberts I, Clarke M, DiGuiseppi C, Pratap S, Wentz R, et al. Methods to increase response rates to postal questionnaires. Cochrane Database Syst Rev. 2007 Apr 18;(2):MR000008.

39. Eyerman J, Link M, Mokdad A, Morton J. Assessing the Impact of Methodological Enhancements on Different Subpopulations in an Experiment on the Behavioral Risk Factor Surveillance System. Joint Statistical Meetings. 2003;

40. Felix LM, Burchett HE, Edwards PJ. Factorial trial found mixed evidence of effects of pre-notification and pleading on response to Web-based survey. J Clin Epidemiol. 2011 May;64(5):531-6.

41. Furse DH, Stewart DW, Rados DL. Effects of Foot-in-the-Door, Cash Incentives, and Followups on Survey Response. Journal of Marketing Research. 1981;18(4):473-8.

42. Gattellari M, Zwar N, Worthington JM. No difference demonstrated between faxed or mailed prenotification in promoting questionnaire response among family physicians: a randomized controlled trial. Journal of Clinical Epidemiology. 2012 May $1 ; 65(5): 544-52$. 
medRxiv preprint doi: https://doi.org/10.1101/2021.02.19.21252094; this version posted February 23, 2021. The copyright holder for this preprint (which was not certified by peer review) is the author/funder, who has granted medRxiv a license to display the preprint in perpetuity. It is made available under a CC-BY-NC-ND 4.0 International license.

43. Gerritsen M, Palmen M-J. The effect of prenotification techniques on refusal rate in telephone surveys: A real-life study in light of the Compliance and Elaboration Likelihood Theories. Document Design. 2002 Jan 1;3(1):16-28.

44. Goldstein KM, Jennings MK. The Effect of Advance Letters on Cooperation in a List Sample Telephone Survey. The Public Opinion Quarterly. 2002;66(4):608-17.

45. Grande ED, Chittleborough CR, Campostrini S, Dollard M, Taylor AW. Pre-Survey Text Messages (SMS) Improve Participation Rate in an Australian Mobile Telephone Survey: An Experimental Study. PLOS ONE. 2016 Feb 26;11(2):e0150231.

46. Grava-Gubins I, Scott S. Effects of various methodologic strategies: Survey response rates among Canadian physicians and physicians-in-training. Canadian Family Physician. 2008 Oct 1;54(10):1424-30.

47. Green O, Ayalon L. Improving the Cooperation Rate of Older Adults and Their Caregivers in Research Surveys. GER. 2015;61(4):355-63.

48. Greenfield D, Moldovan M, Westbrook M, Jones D, Low L, Johnston B, et al. An empirical test of short notice surveys in two accreditation programmes. Int J Qual Health Care. 2012 Feb;24(1):65-71.

49. Groves R, Snowden C. The effects of advanced letters on response rates in linked telephone surveys [Internet]. 1987. Available from: http://ww2.amstat.org/sections/srms/Proceedings/papers/1987_113.pdf

50. Hammink A, Giesen P, Wensing M. Pre-notification did not increase response rate in addition to follow-up: a randomized trial. Journal of Clinical Epidemiology. $2010 \mathrm{Nov}$ $1 ; 63(11): 1276-8$.

51. Hembroff LA, Rusz D, Rafferty A, McGee H, Ehrlich N. The Cost-Effectiveness of Alternative Advance Mailings in a Telephone Survey. Public Opin Q. 2005 Jan 1;69(2):232-45.

52. Henri J-F, Thibodeau N. Follow-ups and mail survey response rates in management accounting research. 2012; Available from:

https://www.researchgate.net/profile/Nicole_Thibodeau/publication/260638485_FOLL OW-

UPS_AND_MAIL_SURVEY_RESPONSE_RATES_IN_MANAGEMENT_ACCOUNTI NG_RESEARCH/links/02e7e531e163cd3ace000000.pdf

53. Ho-A-Yun J, Crawford F, Newton J, Clarkson J. The effect of advance telephone prompting in a survey of general dental practitioners in scotland: a randomised controlled trial. Community Dent Health. 2007 Dec;24(4):233-7.

54. Hoisak JDP, Pawlicki T, Kim G-Y, Fletcher R, Moore KL. Improving linear accelerator service response with a real-time electronic event reporting system. Journal of Applied Clinical Medical Physics. 2014 Sep 1;15(5):257-64.

55. Iredell $H$, Shaw $T$, Howat $P$, James $R$, Granich J. Introductory postcards: do they increase response rate in a telephone survey of older persons? Health Educ Res. 2004 Apr 1;19(2):159-64.

56. Jacob RT, Jacob B. Prenotification, Incentives, and Survey Modality: An Experimental Test of Methods to Increase Survey Response Rates of School Principals. Journal of Research on Educational Effectiveness. 2012 Oct 1;5(4):40118.

57. Kaplowitz MD, Hadlock TD, Levine R. A Comparison of Web and Mail Survey Response Rates. Public Opin Q. 2004 Mar 1;68(1):94-101.

58. Keding A, Brabyn S, MacPherson H, Richmond SJ, Torgerson DJ. Text message reminders to improve questionnaire response rates. Journal of Clinical Epidemiology. 2016 Nov 1;79:90-5.

59. Keusch F. How to Increase Response Rates in List-Based Web Survey Samples. Social Science Computer Review. 2012 Aug 1;30(3):380-8.

60. Koitsalu M, Eklund M, Adolfsson J, Grönberg H, Brandberg Y. Effects of prenotification, invitation length, questionnaire length and reminder on participation rate: a quasi-randomised controlled trial. BMC Medical Research Methodology. 2018 Jan $5 ; 18(1): 3$. 
medRxiv preprint doi: https://doi.org/10.1101/2021.02.19.21252094; this version posted February 23, 2021. The copyright holder for this preprint (which was not certified by peer review) is the author/funder, who has granted medRxiv a license to display the preprint in perpetuity. It is made available under a CC-BY-NC-ND 4.0 International license .

61. Koopman L, Donselaar L (C) G, Rademakers JJ, Hendriks M. A prenotification letter increased initial response, whereas sender did not affect response rates. Journal of Clinical Epidemiology. 2013 Mar 1;66(3):340-8.

62. Kulka R, Shirey S, Moore P, Woodbury N. A factorial experiment on the responses of professional nurses to a national mail survey [Internet]. 1981. Available from: https://ww2.amstat.org/sections/srms/Proceedings/papers/1981_057.pdf

63. Lacey RJ, Wilkie R, Wynne-Jones G, Jordan JL, Wersocki E, McBeth J. Evidence for strategies that improve recruitment and retention of adults aged 65 years and over in randomised trials and observational studies: a systematic review. Age Ageing. 2017 Nov 1;46(6):895-903.

64. Lalasz C, Doane M, Victoria S, Veronica D. Examining the Effect of Prenotification Postcards on Online Survey Response Rate in a University Graduate Sample. Survey Practice. 2014;7(3).

65. Leathem CS, Cupples ME, Byrne MC, O'Malley M, Houlihan A, Murphy AW, et al. Identifying strategies to maximise recruitment and retention of practices and patients in a multicentre randomised controlled trial of an intervention to optimise secondary prevention for coronary heart disease in primary care. BMC Medical Research Methodology. 2009 Jun 19;9(1):40.

66. Libby G, Bray J, Champion J, Brownlee LA, Birrell J, Gorman DR, et al. Prenotification Increases Uptake of Colorectal Cancer Screening in All Demographic Groups: A Randomized Controlled Trial. J Med Screen. 2011 Mar 1;18(1):24-9.

67. Link MW, Mokdad A. Advance Letters as a Means of Improving Respondent Cooperation in Random Digit Dial StudiesA Multistate Experiment. Public Opin Q. 2005 Jan 1;69(4):572-87.

68. Lusinchi D. Increasing Response Rates \& Data Quality of Web Surveys: PreNotification and Questionnaire Paging Format. Far West Research. 2007;

69. Lynn P, Smith P, Turner R. Assessing the effects of an advance letter for a personal interview survey - ProQuest [Internet]. 1998 [cited 2018 Aug 29]. Available from: https://search.proquest.com/openview/c2ef65999340318bed063df846910e7a/1 ?pqorigsite $=$ gscholar $\& \mathrm{cbl}=45628$

70. Lynn P. Targeted Appeals for Participation in Letters to Panel Survey Members. Public Opin Q. 2016 Jan 1;80(3):771-82.

71. MacLennan G, McDonald A, McPherson G, Treweek S, Avenell A. Advance telephone calls ahead of reminder questionnaires increase response rate in nonresponders compared to questionnaire reminders only: The RECORD phone trial. Trials. 2014 Jan 8;15:13.

72. Man M-S, Rick J, Bower P, on behalf of the Healthlines Study Group, on behalf of the MRC-START Group. Improving recruitment to a study of telehealth management for long-term conditions in primary care: two embedded, randomised controlled trials of optimised patient information materials. Trials. 2015 Jul 19;16(1):309.

73. Martins Y, Lederman RI, Lowenstein CL, Joffe S, Neville BA, Hastings BT, et al. Increasing response rates from physicians in oncology research: a structured literature review and data from a recent physician survey. Br J Cancer. 2012 Mar 13;106(6):1021-6.

74. McCallister LA, Otto B. Exploring the Impact of E-mail and Postcard Prenotification on Response Rates to a Mail Survey in an Academic Setting. Journal of Applied Social Science. 2008 Mar 1;2(1):94-103.

75. McLean SA, Paxton SJ, Massey R, Mond JM, Rodgers B, Hay PJ. Prenotification but not envelope teaser increased response rates in a bulimia nervosa mental health literacy survey: A randomized controlled trial. J Clin Epidemiol. 2014 Aug;67(8):8706.

76. Mickey R, Vacek P. Effects of survey mode and advance letters on contact and interview completion rates for population-based surveys of women. Proceedings of the Section on Survey Research Methods American Statistical Association. 1999; 
medRxiv preprint doi: https://doi.org/10.1101/2021.02.19.21252094; this version posted February 23, 2021. The copyright holder for this preprint (which was not certified by peer review) is the author/funder, who has granted medRxiv a license to display the preprint in perpetuity. It is made available under a CC-BY-NC-ND 4.0 International license.

77. Millar MM, Dillman DA. Improving Response to Web and Mixed-Mode Surveys. Public Opin Q. 2011 Jan 1;75(2):249-69.

78. Miner MH. Preliminary Contact With a Mailed Follow-Up Survey: Effect on Rate of Response of Former Mental Health Patients. Eval Rev. 1983 Jun 1;7(3):385-96.

79. Mitchell N, Hewitt CE, Lenaghan E, Platt E, Shepstone L, Torgerson DJ, et al. Prior notification of trial participants by newsletter increased response rates:a randomized controlled trial. Journal of Clinical Epidemiology. 2012 Dec;65:1348-52.

80. Mitchell V-W, Brown J. Research note: A cost-benefit analysis of letter prenotification and follow-up. Journal of Marketing Management. 1997 Nov 1;13(8):853-66.

81. O'Carroll RE, Steele RJ, Libby G, Brownlee L, Chambers JA. Anticipated regret to increase uptake of colorectal cancer screening in Scotland (ARTICS): study protocol for a randomised controlled trial. BMC Public Health. 2013 Sep 16;13(1):849.

82. Pitiyanuwat S, Phattharayuttawat S. Prenotification, Ink Color and Return Deadline: Effects on Response Rates and Sincerity of Responses [Internet]. 1991 [cited 2018 Aug 29]. Available from: https://eric.ed.gov/?id=ED334221

83. Porter SR, Whitcomb ME. Mixed-Mode Contacts In Web SurveysPaper is Not Necessarily Better. Public Opin Q. 2007 Jan 1;71(4):635-48.

84. Rao K, Kaminska O, McCutcheon AL. Recruiting Probability Samples for a MultiMode Research Panel with Internet and Mail Components. Public Opin Q. 2010 Jan $1 ; 74(1): 68-84$.

85. Senore C, Ederle A, DePretis G, Magnani C, Canuti D, Deandrea S, et al. Invitation strategies for colorectal cancer screening programmes: The impact of an advance notification letter. Prev Med. 2015 Apr;73:106-11.

86. Singer E, Hoewyk V, JOHN, Maher MP. Experiments with Incentives in Telephone Surveys. Public Opin Q. 2000 Aug 1;64(2):171-88.

87. Slater M, Kiran T. Measuring the patient experience in primary care: Comparing email and waiting room survey delivery in a family health team. Canadian Family Physician. 2016 Dec 1;62(12):e740-8.

88. Smith W, Chey T, Jalaludin B, Salkeld G, Capon T. Increasing response rates in telephone surveys: a randomized trial. J Public Health (Oxf). 1995 Mar 1;17(1):33-8.

89. Snow RE, Prather JE, Hutcheson JD. Program Evaluation Using a Follow-Up Telephone Survey: The Effects of a Prior Letter. Eval Rev. 1986 Feb 1;10(1):85-94.

90. Starr K, McPherson G, Forrest M, Cotton SC. SMS text pre-notification and delivery of reminder e-mails to increase response rates to postal questionnaires in the SUSPEND trial: a factorial design, randomised controlled trial. Trials [Internet]. 2015 Jul 8;16. Available from: https://www.ncbi.nlm.nih.gov/pmc/articles/PMC4494692/

91. Steeh C, Buskirk TD, Callegaro M. Using Text Messages in U.S. Mobile Phone Surveys. Field Methods. 2007 Feb 1;19(1):59-75.

92. Todd AL, Porter M, Williamson JL, Patterson JA, Roberts CL. Pre-notification letter type and response rate to a postal survey among women who have recently given birth. BMC Medical Research Methodology. 2015 Dec 1;15(1):104.

93. Traugott M, Goldstein K. Evaluating dual frame samples and advance letters as a means of increasing response rates. Public Opinion Quarterly. 1987;51:522-39.

94. Traugott MW, Groves RM, Lepkowski JM. Using dual frame designs to reduce nonresponse in telephone surveys. Public Opin Q. 1987 Jan 1;51(4):522-39.

95. Treweek S, Mitchell E, Pitkethly M, Cook J, Kjeldstrøm M, Taskila T, et al. Strategies to improve recruitment to randomised controlled trials. Cochrane Database Syst Rev. 2010 Jan 20;(1):MR000013.

96. Treweek S, Pitkethly M, Cook J, Fraser C, Mitchell E, Sullivan F, et al. Strategies to improve recruitment to randomised trials. Cochrane Database Syst Rev. 2018 22;2:MR000013.

97. van Gelder MMHJ, Vlenterie R, IntHout J, Engelen LJLPG, Vrieling A, van de Belt $\mathrm{TH}$. Most response-inducing strategies do not increase participation in observational studies: a systematic review and meta-analysis. J Clin Epidemiol. 2018 Jul;99:1-13. 
medRxiv preprint doi: https://doi.org/10.1101/2021.02.19.21252094; this version posted February 23, 2021. The copyright holder for this preprint (which was not certified by peer review) is the author/funder, who has granted medRxiv a license to display the preprint in perpetuity. It is made available under a CC-BY-NC-ND 4.0 International license .

98. Veen F van, Göritz AS, Sattler S. Response Effects of Prenotification, Prepaid Cash, Prepaid Vouchers, and Postpaid Vouchers: An Experimental Comparison. Social Science Computer Review. 2016 Jun 1;34(3):333-46.

99. von der Lippe E, Schmich P, Lange C. Advance letters as a way of reducing nonresponse in a National Health Telephone Survey: Differences between listed and unlisted numbers. Survey Research Methods. 2011;5(3):103-16.

100. Wagner J, Schroeder HM, Piskorowski A, Ursano RJ, Stein MB, Heeringa SG, et al. Timing the Mode Switch in a Sequential Mixed-Mode Survey: An Experimental Evaluation of the Impact on Final Response Rates, Key Estimates, and Costs. Social Science Computer Review. 2017 Apr 1;35(2):262-76.

101. Weiner MD, Puniello OT, Noland RB. Conducting Efficient Transit Surveys of Households Surrounding Transit-Oriented Developments. Transportation Research Record: Journal of the Transportation Research Board. 2016 Jan 1;2594:44-50.

102. Westrick SC, Mount JK. Evaluating telephone follow-up of a mail survey of community pharmacies. Research in Social and Administrative Pharmacy. 2007 Jun 1;3(2):160-82.

103. Woodruff SI, Mayer JA, Clapp E. Effects of an Introductory Letter on Response Rates to a Teen/Parent Telephone Health Survey. Eval Rev. 2006 Dec 1;30(6):817-23.

104. Xie Y, Ho SC. Prenotification had no additional effect on the response rate and survey quality: a randomized trial. J Clin Epidemiol. 2013 Dec;66(12):1422-6.

105. Young T, Hopewell S. Methods for obtaining unpublished data. Cochrane Database Syst Rev. 2011 Nov 9;(11):MR000027.

106. social-research-practice-journal-issue-01-winter-2015.pdf [Internet]. [cited 2018 Aug 29]. Available from: http://the-sra.org.uk/wp-content/uploads/socialresearch-practice-journal-issue-01-winter-2015.pdf\#page $=5$

107. Parsons RJ, Medford TS. The effect of advance notice in mail surveys of homogeneous groups. Public Opinion Quarterly 1972;36:258-9.

108. Kephart WM, Bressler M. Increasing the response to mail questionnaires: a research study. Public Opinion Quarterly 1958;21:123-32.

109. Stafford JE. Influence of preliminary contact on mail returns. Journal of Marketing Research 1966;3:410-1.

110. Ford NM. The advance letter in mail surveys. Journal of Marketing Research 1967;4:202-4.

111. Myers JH, Haug AF. How a preliminary letter affects mail survey returns and costs. Journal of Advertising Research 1969;9(3):37-9.

112. Pucel DJ, Nelson HF, Wheeler DN. Questionnaire followup returns as a function of incentives and responder characteristics. Vocational Guidance Quarterly 1971; March: 188-93.

113. Jobber D, Sanderson S. The effects of a prior letter and coloured questionnaire paper on mail survey response rates. Journal of the Market Research Society 1983;25(4):339-49.

114. Wynn GW, McDaniel SW. The effect of alternative foot-in the-door manipulations on mailed questionnaire response rate and quality. Journal of the Market Research Society 1985; 27(1):15-26.

115. Kindra GS, McGown KL, Bougie M. Stimulating responses to mailed questionnaires. An experimental study. International Journal of Research in Marketing 1985;2:219-35.

116. Ogbourne AC, Rush B, Fondacaro R. Dealing with nonrespondents in a mail survey of professionals. Evaluation \& the Health Professions 1986;9(1):121-8.

117. Spry VM, Hovell MF, Sallis JG, Hofsteter CR, Elder JP, Molgaard CA. Recruiting survey respondents to mailed surveys: controlled trials of incentives and prompts. American Journal of Epidemiology 1989;130(1):166-72. 
medRxiv preprint doi: https://doi.org/10.1101/2021.02.19.21252094; this version posted February 23, 2021. The copyright holder for this preprint (which was not certified by peer review) is the author/funder, who has granted medRxiv a license to display the preprint in perpetuity. It is made available under a CC-BY-NC-ND 4.0 International license.

118. Shiono PH, Klebanoff MA. The effect of two mailing strategies on the response to a survey of physicians. American Journal of Epidemiology 1991;134(5):539-42.

119. Murphy PM, Daley JM. Exploring the effects of postcard prenotification on industiral firms' response to mail surveys. Journal of the Market Research Society 1991;33(4):335-41.

120. Sutton RJ, Zeitz LL. Multiple prior notifications, personalization, and reminder surveys. Marketing Research 1992;4:14-21.

121. Gillpatrick TR, Harmon RR, Tseng LP. The effect of a nominal monetary gift and different contacting approaches on mail survey response among engineers. IEE Transactions of Engineering Management 1994;41:285-90.

122. Wright $M$. The effect of pre-notification on mail survey response rates: an experimental result. Marketing Bulletin 1995;6:59-64.

123. Etter J-F, Perneger TV, Laporte J-D. Unexpected effects of a prior feedback letter and a professional layout on the response rate to a mail survey in Geneva. Journal of Epidemiology and Community Health 1998;52:128-9.

124. Pirotta M, Gunn J, Farish S, Karabatsos G. Primer postcard improves postal survey response rates. Australian and New Zealand Journal of Public Health 1999;23(2):196-7.

125. Whiteman MK, Langenberg P, Kjerulff K, McCarter R, Flaws JA. A randomized trial of incentives to improve response rates to a mailed women's health questionnaire. Journal of Women's Health 2003;12(8):821-8.

126. Newby R,Watson J,Woodliff D. SME survey methodology: response rates, data quality, and cost effectiveness. Entrepreneurship Theory and Practice 2003:163-72.

127. Scott FG. Mail questionnaires used in a study of older women. Sociology and Social Research 1957;41:281-4.

128. Bergen AV, Spitz JC. [De introductie van een schriftelijke enquete]. Nederlandsch Tijdschrift voor Psychologie 1957;12: 68-96.

129. Wiseman F. Methodological bias in public opinion surveys. Public Opinion Quarterly 1972;36:105-8.

130. Dillman DA, Frey JH. Contribution of personalization to mail questionnaire response as an element of a previously tested method. Journal of Applied Psychology 1974;59(3): 297-301.

131. Childers TL, Skinner SJ. Gaining respondent cooperation in mail surveys through prior commitment. Public OpinionQuarterly 1979;43:558-61.

132. Furst LG, Blitchington WP. The use of a descriptive cover letter and secretary pre-letter to increase response rate in a mailed survey. Personnel Psychology 1979;32:155-9.

133. Hornik J. Impact of pre-call request form and gender interaction on response to a mail survey. Journal of Marketing Research 1982;19:144-51.

134. Nichols S, Waters WE, Woolaway M, Hamilton-Smith MB. Evaluation of the effectiveness of a nutritional health education leaflet in changing public knowledge and attitudes about eating and health. Journal of Human Nutrition and Dietetics 1988;1:233-8.

135. Martin WS, Duncan WJ, Powers TL, Sawyer JC. Costs and benefits of selected response inducement techniques in mail survey research. Journal of Business Research 1989;19:67-79.

136. Albaum G, Strandskov J. Participation in a mail survey of international marketers: effects of pre-contact and detailed project explanation. Journal of Global Marketing 1989;2(4): 7-23.

137. Faria AJ, Dickinson JR, Filipic TV. The effect of telephone versus letter prenotification on mail survey response rate, speed, quality and cost. Journal of the Market Research Society 1990;32(4):551-68. 
medRxiv preprint doi: https://doi.org/10.1101/2021.02.19.21252094; this version posted February 23, 2021. The copyright holder for this preprint (which was not certified by peer review) is the author/funder, who has granted medRxiv a license to display the preprint in perpetuity.

It is made available under a CC-BY-NC-ND 4.0 International license .

138. Duhan DF, Wilson RD. Prenotification and industrial survey responses. Industrial Marketing Management 1990; 19:95-105.

139. Chebat J-C, Picard J. Does prenotification increase response rates in mail surveys? A self-perception approach. Journal of Social Psychology 1991;13(4):47781.

140. Osborne MO, Ward J, Boyle C. Effectiveness of telephone prompts when surveying general practitioners: a randomised trial. Australian Family Physician 1996;25(1):S41-3.

141. Temple-Smith M, Mulvey G, Doyle W. Maximising response rates in a survey of general practitioners - lessons from a Victorian survey on sexually transmissible diseases. Australian Family Physician 1998;27(Suppl 1):S15-8.

142. Eaker S, Bergstrom R, Bergstrom A, Hans-Olov A, Nyren O. Response rate to mailed epidemiologic questionnaires: a population-based randomized trial of variations in design and mailing routines. Americal Journal of Epidemiology 1998;147(1):74-82.

143. Cycyota C, Harrison DA. Enhancing survey response rates at the executive level: Are employee- or consumer-level techniques effective?. Journal of Management 2002;28(2): 151-76.

144. Napoles-Springer AM, Fongwa MN, Stewart AL, Gildengorin G, Perez-Stable EJ. The effectiveness of an advance notice letter on the recruitment of African Americans and Whites for a mailed patient satisfaction survey. Journal of Aging \& Health 2004;16(5 Suppl): 124S-36S.

145. Harrison RA, Cock D. Increasing response to a postal survey of sedentary patients - a randomised controlled trial. BMC Health Services Research 2004;4(31):1-5.

146. Mann CB. Do advance letters improve preelection forecast accuracy?. Public Opinion Quarterly 2005;69(4):561-71.

147. Drummond FJ, Sharp L, Carsin AE, Kelleher T, Comber H. Questionnaire order significantly increased response to a postal survey sent to primary care physicians. Journal of Clinical Epidemiology 2008;61:177-85. 
medRxiv preprint doi: https://doi.org/10.1101/2021.02.19.21252094; this version posted February 23, 2021. The copyright holder for this preprint (which was not certified by peer review) is the author/funder, who has granted medRxiv a license to display the preprint in perpetuity.

It is made available under a CC-BY-NC-ND 4.0 International license. 


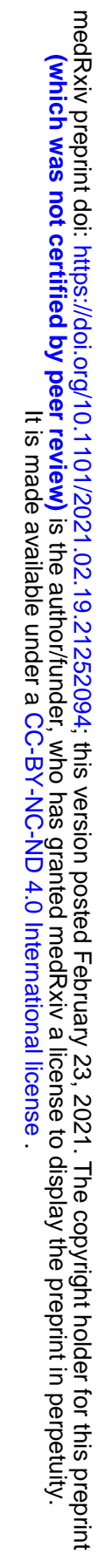


medRxiv preprint doi: https://doi.org/10.1101/2021.02.19.21252094; this version posted February 23, 2021. The copyright holder for this preprint (which was not certified by peer review) is the author/funder, who has granted medRxiv a license to display the preprint in perpetuity.

It is made available under a CC-BY-NC-ND 4.0 International license . 
medRxiv preprint doi: https://doi.org/10.1101/2021.02.19.21252094; this version posted February 23, 2021. The copyright holder for this preprint (which was not certified by peer review) is the author/funder, who has granted medRxiv a license to display the preprint in perpetuity.

\section{It is made available under a CC-BY-NC-ND 4.0 International license.}

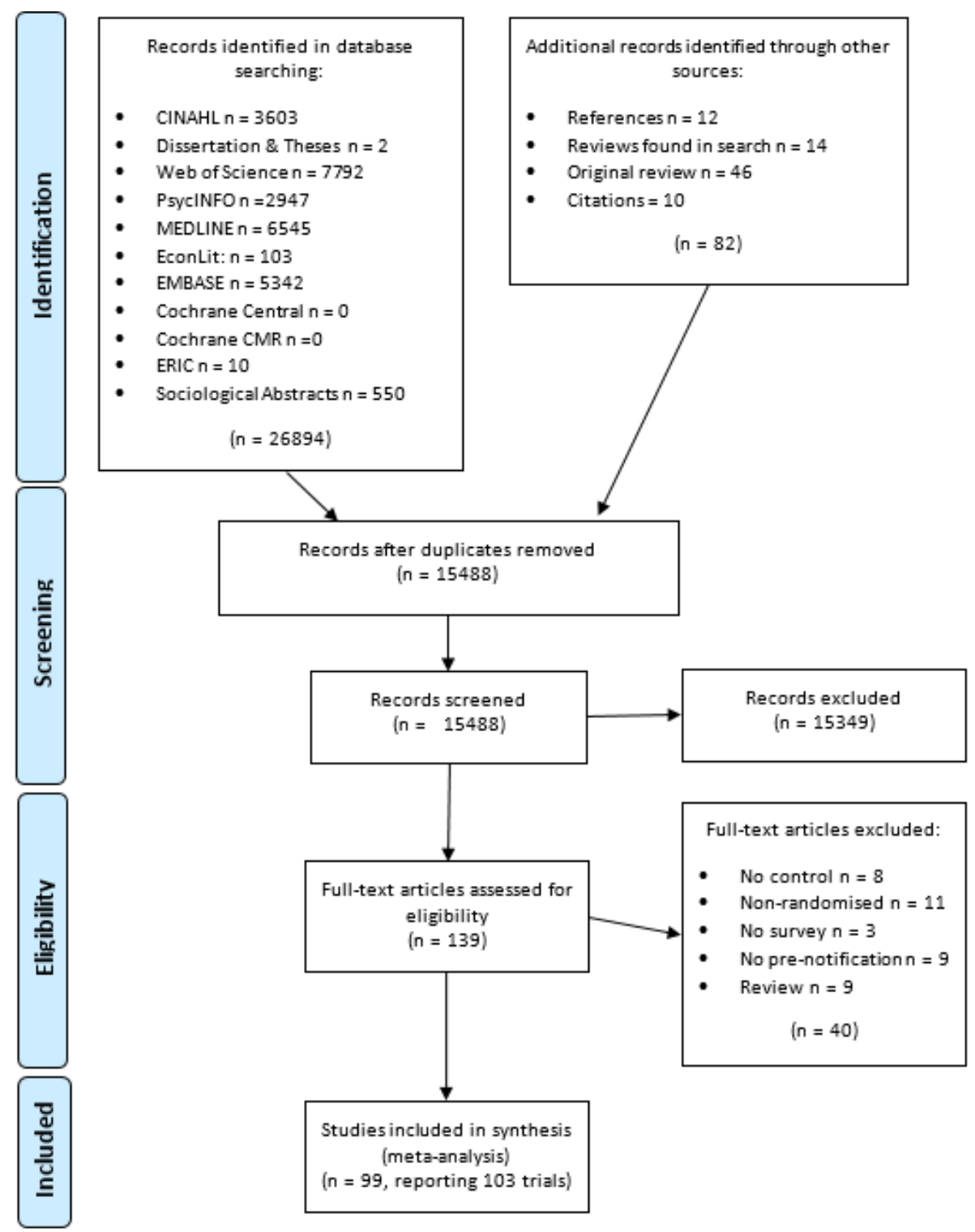

Figure 1: PRISMA flow diagram of information through the different phase of the systematic review 
medRxiv preprint doi: https://doi.org/10.1101/2021.02.19.21252094; this version posted February 23, 2021. The copyright holder for this preprint (which was not certified by peer review) is the author/funder, who has granted medRxiv a license to display the preprint in perpetuity.

It is made available under a CC-BY-NC-ND 4.0 International license .
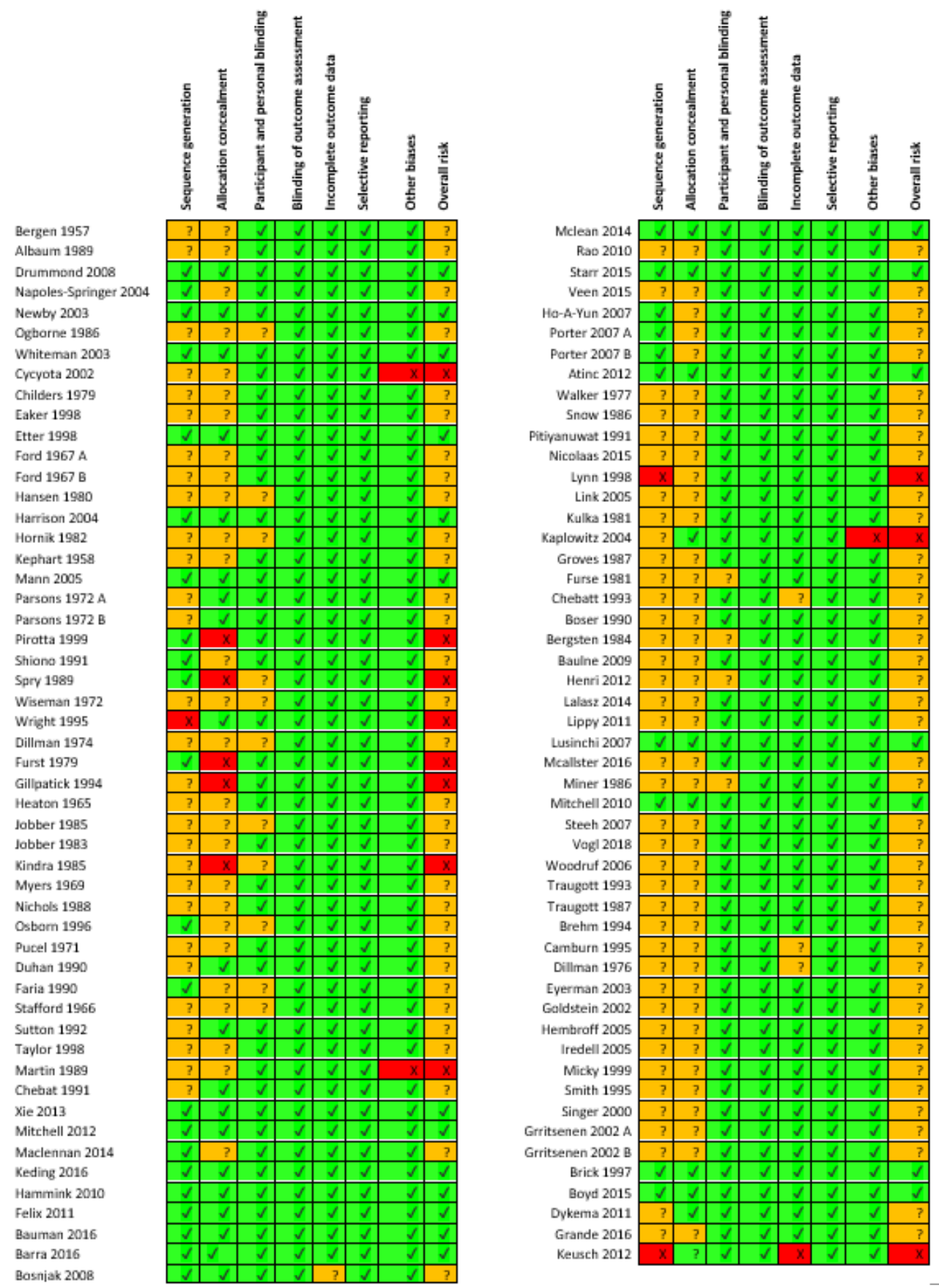

Figure 1: Risk of bias summary figure illustrating judgement about each risk of bias item for each included study. 
medRxiv preprint doi: https://doi.org/10.1101/2021.02.19.21252094; this version posted February 23, 2021. The copyright holder for this preprint (which was not certified by peer review) is the author/funder, who has granted medRxiv a license to display the preprint in perpetuity.

\section{It is made available under a CC-BY-NC-ND 4.0 International license .}

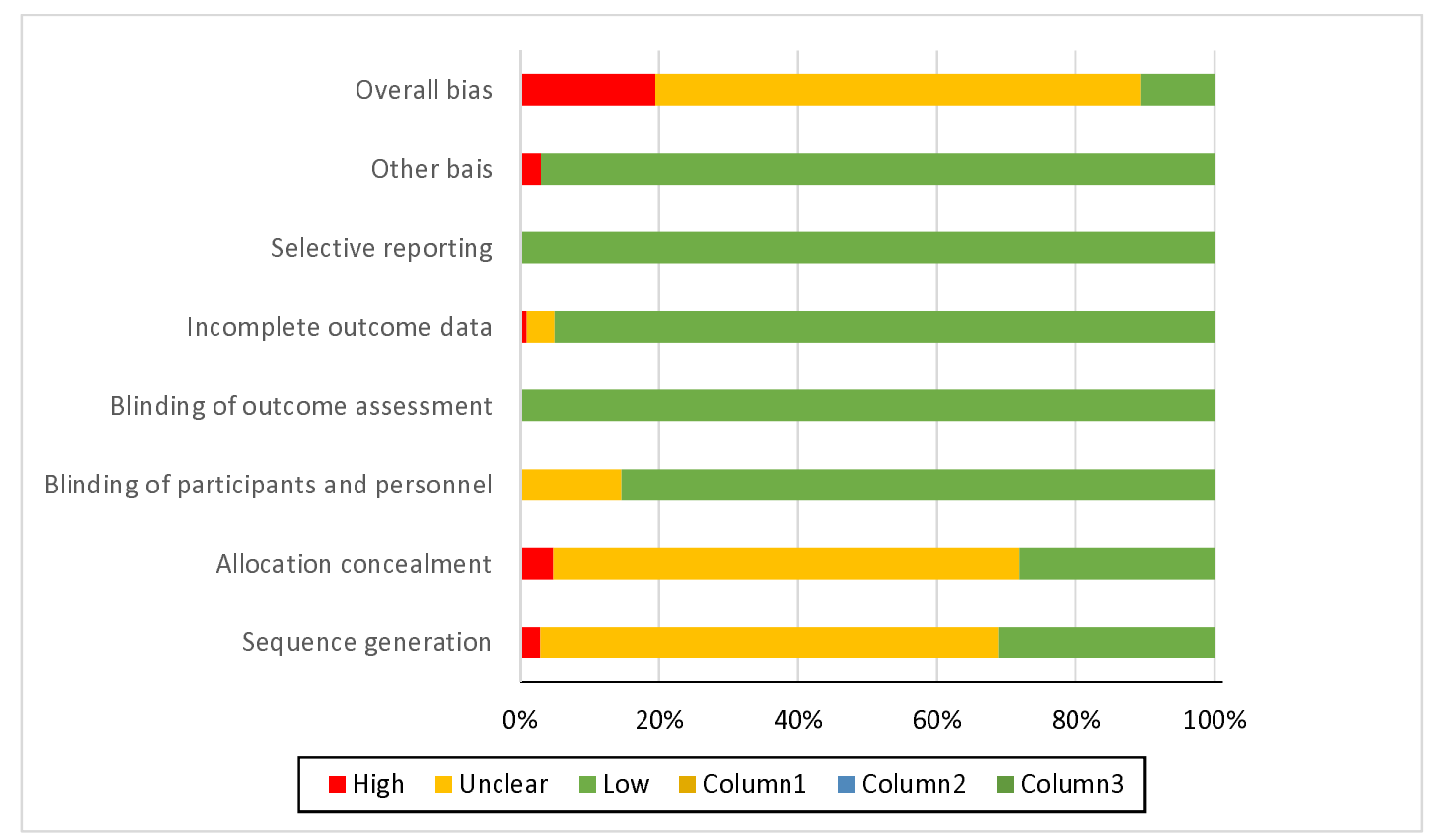

Figure 1: Risk of bias graph illustration judgments about each risk of bias item presented as percentages across all included studies. 
medRxiv preprint doi: https://doi.org/10.1101/2021.02.19.21252094; this version posted February 23, 2021. The copyright holder for this preprint (which was not certified by peer review) is the author/funder, who has granted medRxiv a license to display the preprint in perpetuity.

\section{It is made available under a CC-BY-NC-ND 4.0 International license .}

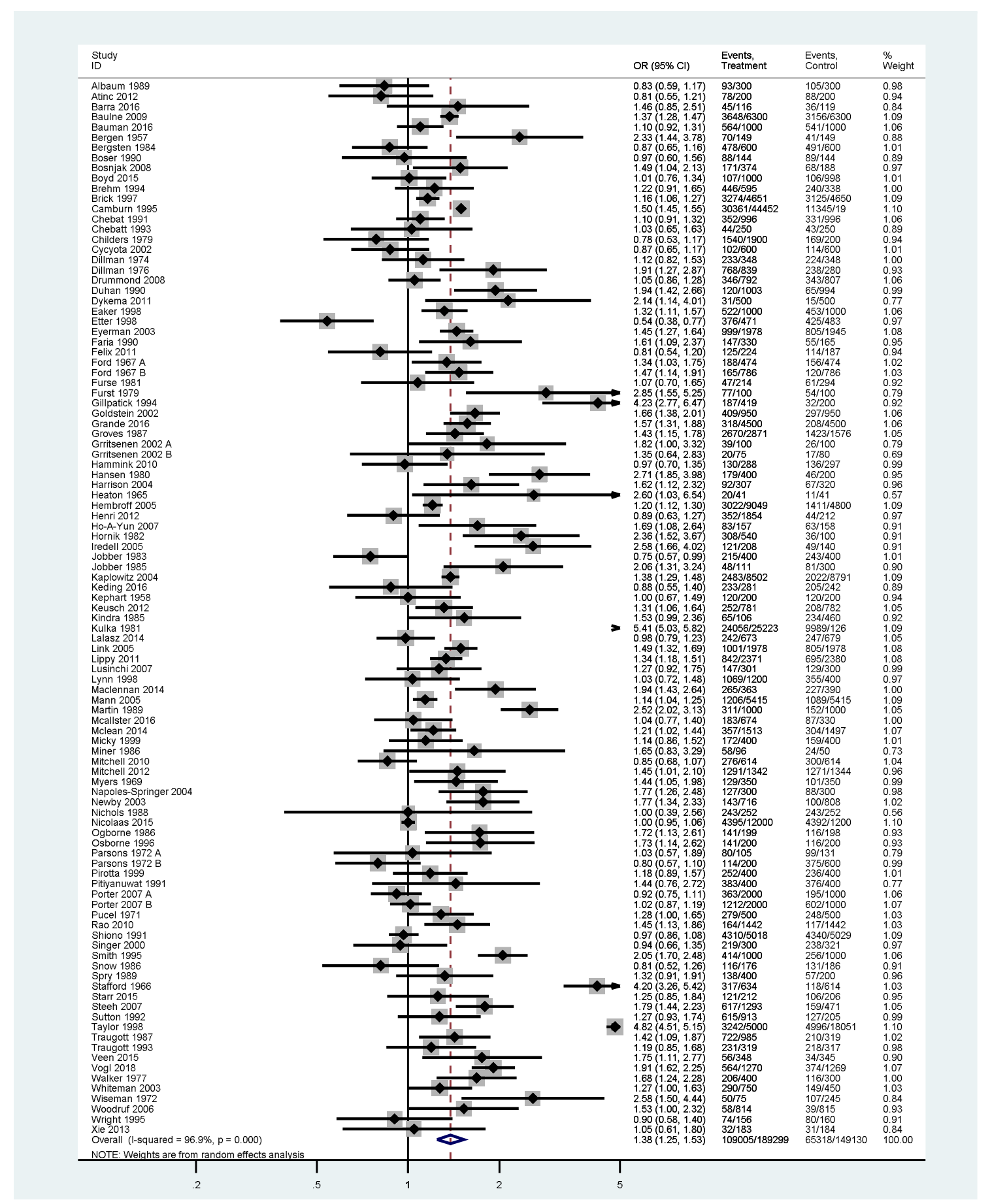

Figure 1: Forest plot of overall response after final follow-up with pre-notification versus no pre-notification. 


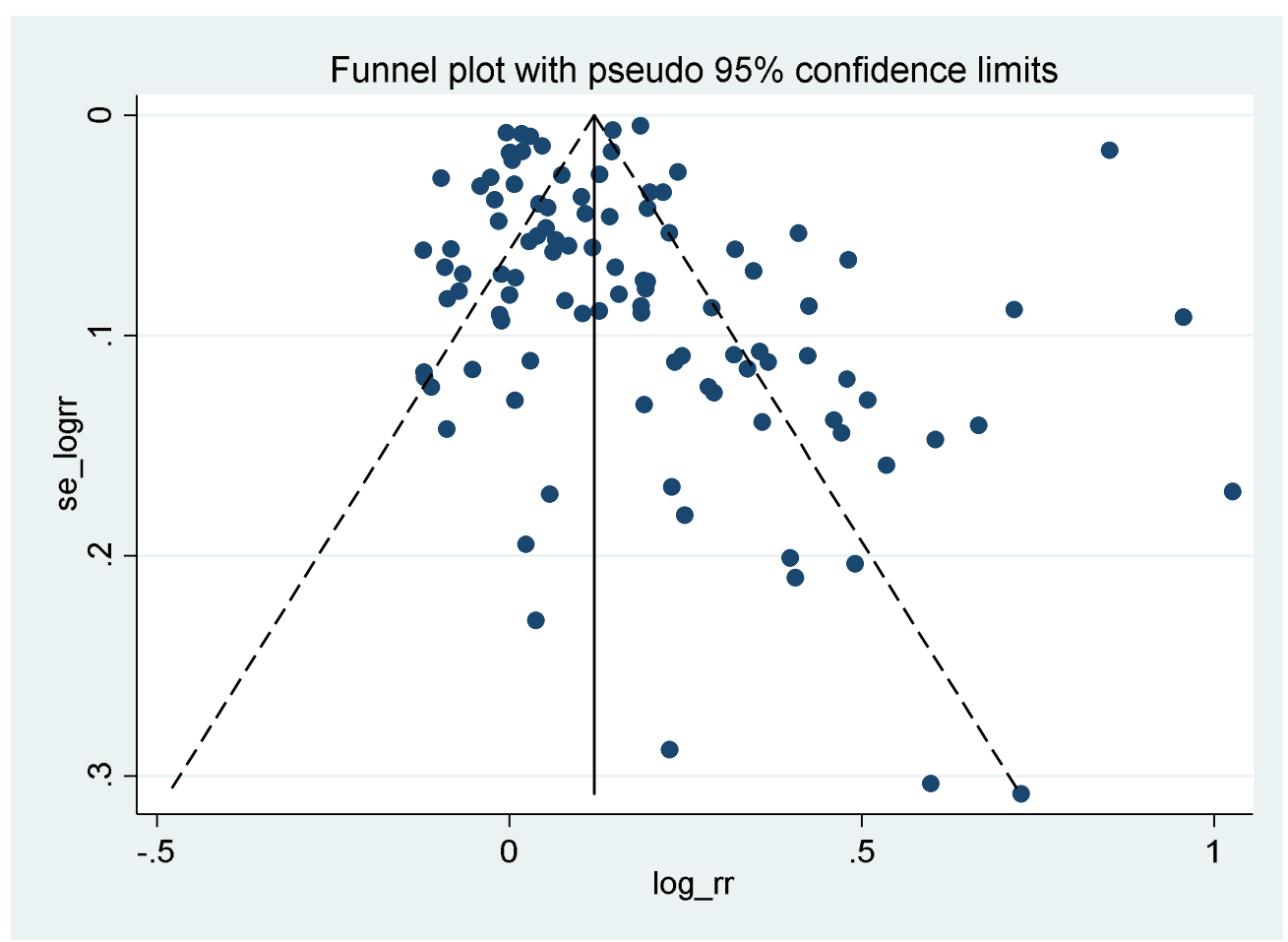

Figure 5: Funnel plot with pseudo 95\% confidence limits for response after final follow-up. 
medRxiv preprint doi: https://doi.org/10.1101/2021.02.19.21252094; this version posted February 23, 2021. The copyright holder for this preprint (which was not certified by peer review) is the author/funder, who has granted medRxiv a license to display the preprint in perpetuity.

\section{It is made available under a CC-BY-NC-ND 4.0 International license.}

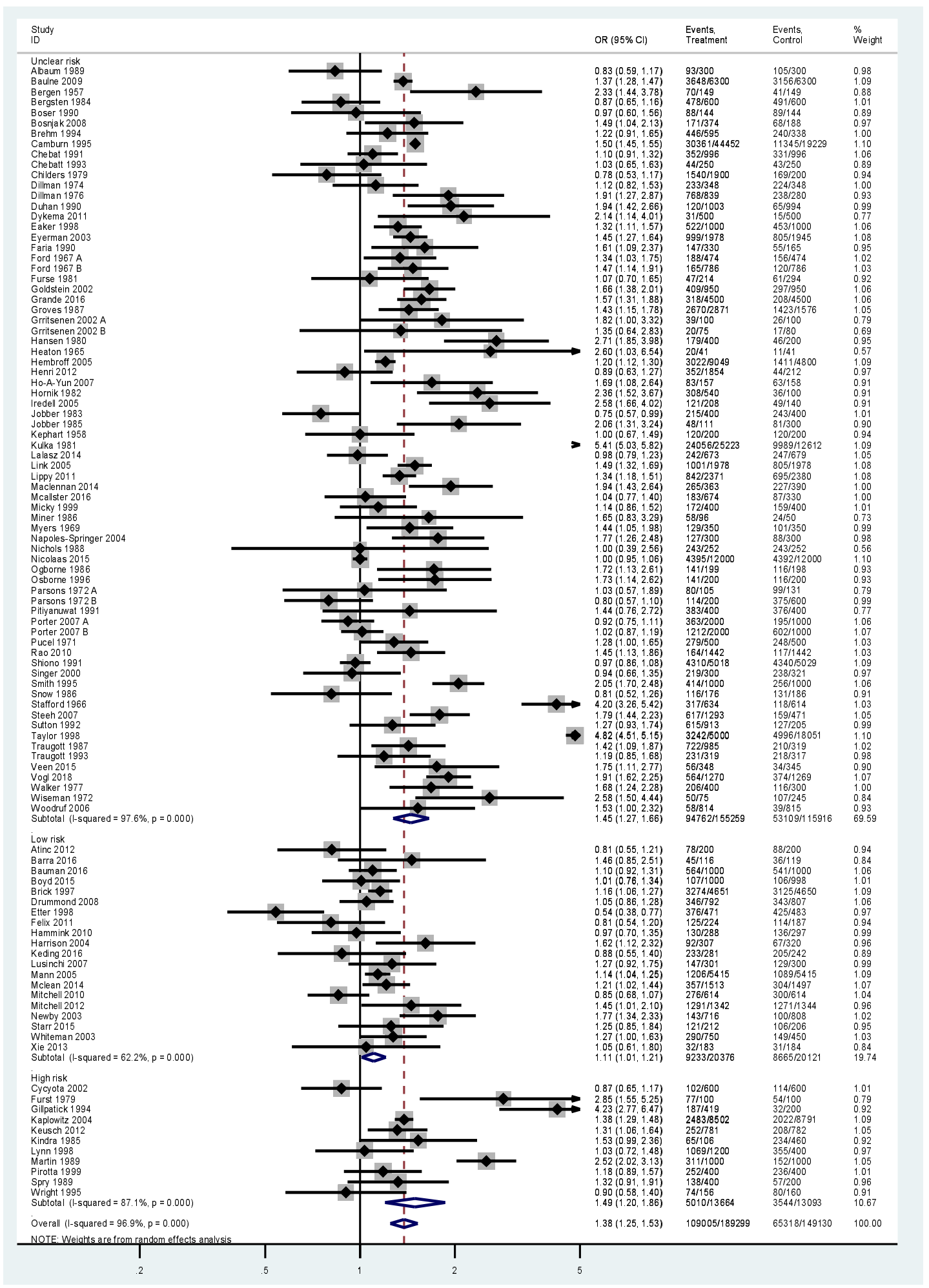

Figure 6: Forest plot of response after final follow-up with pre-notification versus no pre-notification, stratified by risk of bias. 